\title{
UK's Free Trade Agreements with Non-EU Countries: the Case of the Black Sea Region
}

\section{Yuliia Shevchenko ${ }^{1}$}

Received: 30.06 .2021

Available online: 20.12 .2021

\section{Abstract}

With the end of the Brexit transition period and its final departure from the EU, the United Kingdom lost its access to the EU trade agreements that its economy had previously benefited from. Therefore, the UK has been determined to preserve the preferential trading terms with states and trading blocs that used to be covered during its membership in the EU, and introduced a number of Free Trade Agreements (FTA) to guarantee a smooth transition both for the UK and non-EU countries' economies with which it has extensive trade. The objective is to analyze the signing of Free Trade Agreements between UK and non-EU countries, namely, Georgia, Moldova, Ukraine and Turkey. The methodology is based on comparative case-by-case study. The results indicate that UK's trade with the countries in Black Sea region (also quite affiliated with the EU) is going to gain more importance, which will broaden the opportunities for the UK become more involved in the economy of the region and, potentially, build stronger and independent political ties with the countries studied.

Key words: FTA, Brexit, Black Sea region, non-EU member countries

JEL: F50

\section{Introduction}

With the UK's ultimate exit from the EU, the UK's economy lost access to EU trade deals from which it had previously benefited. Through membership in the EU, the UK participated in around 40 free trade agreements, covering more than 70 countries (Edgington, 2021). Meanwhile, the negotiated deal for future trading relationship with the EU, which took

1 Student in the MA program in Political Science at SJTU, China; e-mail address: yulishevchenko27@sjtu.edu. $\mathrm{cn}$ 
effect on January 1, 2021, has proved to be as disruptive to the U.K.'s trade with its erstwhile EU partners as it was predicted. Even though the transition period was expected to cause a certain degree of disturbance in the trade relations with the non-EU member states, it was also viewed as an opportunity to strengthen and enhance the economic ties with third countries on independent terms. As a result, the UK government has been working hard to preserve the preferential trading terms it enjoyed with states and trading blocs during its EU membership, and has introduced a number of Free Trade Agreements to ensure a smooth transition for both the UK and the economies of non-EU states.

The UK concluded continuity agreements with the great majority of those countries that have agreements with the European Union. As of January 1, 2021 this list includes over 60 states. Due to the lateness of several of these accords, their full domestic implementation has yet to be completed, and so-called "bridging procedures" were introduced to assure trade continuity while ratification is completed. Trade is now handled by WTO regulations for those nations that are not yet covered by the continuity agreements (Riddell and Bunch, 2021). Additionally, the UK has been aspiring to establish new trade arrangements by signing an FTA with Australia and negotiating agreements with New Zealand and the US, although not without stumbling blocks. The UK is currently shifting its focus on joining USMCA (Hughes, 2021) and is planning on commencing the negotiations regarding trade agreement with India (Kamath, 2021).

The objective of this study is to analyze the trading relations dynamics between the UK and non-EU member states in the Black Sea region during the transition period and after Brexit, and to determine the possible prospects of UK's engagement in the region in the future. The countries chosen for comparison are Georgia, Moldova, Ukraine and Turkey, all of which have association agreements with the EU in place, regulating trade-related affairs. The primary research question is how UK's "recharge" of trade relations with these countries has impacted the overall engagement of the UK in the Black Sea region.

Previously, the UK's engagement in the region has been rather limited (with the exception of Turkey). The Black Sea region encompasses a range of quite diverse actors: NATO and EU member states, such powerful countries in terms of military capabilities as Turkey and Russia, and also non-EU member states which are politically, economically and ideologically quite affiliated with the EU. Before Brexit, the UK's relations with these countries were primarily managed through Euro-Atlantic institutions. Now that the UK has felt an urge to secure its trade with a large number of trade partners all over the globe, it started to build its independent framework of relations with countries from the region, beginning mostly from trade-related cooperation. Also, as we can see, the UK is leaving potential for future deepening of independent political and institutional relations.

The methodology chosen is based on comparative case-by-case study. The analysis involves the study of documentation (the texts of agreements, as well as explanatory memoranda prepared by the Foreign, Commonwealth and Development Office of the UK) and statistical information on the bilateral trade dynamics between the UK and Georgia, Moldova, Ukraine and Turkey. Since early changes in the trading dynamics between UK and 
countries studied will be illustrated by trade patterns in the years 2021-2022, the results of the study are also based on secondary qualitative and quantitative resources from years 2019-2021 and analysis of data from the period before Brexit and EU's agreements with Ukraine, Moldova and Georgia.

The rise of regionalism has resulted in a large body of theoretical works examining the implications of free trade agreements on bilateral trade flows. Free trade agreements "act as strong building blocks" and "can deliver welfare-improving trade liberalization" (Saggi and Yildiz, 2011: 356, 372). Baier and Bergstrand (2007) through thorough empirical analysis suggest that a bilateral FTA within the span of a decade is guaranteed to increase the trade dynamics up to $100 \%$. Vicard (2011: 190) conducts further investigation of these findings by noting that success of regional trade agreements is determined by the size and GDP of members. Estimation results expose a positive and significant impact of FTAs on trade flows between EU-15 and the Central and Eastern European countries, in comparison with trade flows with countries operating without such FTAs (Caporale et al., 2009: 205). Nevertheless, Yamarik and Ghosh (2005) and Begović (2011) argue that FTAs do not necessarily lead to improvement in trade between member states based on quantitative indicators. Therefore, each case needs to be studied separately by taking into account other circumstances, such as history and political landscape.

\section{UK's free trade agreements with non-EU countries in the Black Sea region}

Despite the fact that UK's trade relations with the countries selected can seem modest in comparison with other trading partners around the globe, the relative geographical proximity of the non-EU countries in the Black Sea region, as well their potential in agrarian and other fields can open new potential for cooperation. Overall, the signing process of the FTA's, especially in the case of Georgia and Ukraine, was rather robust. Political statements made in the texts and alongside the negotiation and signing processes signal the readiness of the UK to secure its relations with countries in the region studied.

Table 1: UK's trade with selected countries: overall exports and imports for 2020

\begin{tabular}{|l|l|l|}
\hline \multicolumn{1}{|c|}{ Country } & \multicolumn{1}{c|}{ Imports (fm) } & \multicolumn{1}{c|}{ Exports (fm) } \\
\hline Georgia & 13 & 65 \\
\hline Ukraine & 560 & 437 \\
\hline Turkey & 8,166 & 4,766 \\
\hline Moldova & 34 & 24 \\
\hline
\end{tabular}

Source: Office for National Statistics, the UK 


\section{Georgia}

Strategic Partnership and Cooperation Agreement signed between Georgia and the United Kingdom in October 2019 was the first such deal in the Black Sea region. Symbolically, Georgia and Great Britain established diplomatic relations for the first time back in 1919, thus, signing the Agreement in 2019 marked an important anniversary.

Over the previous decade, the value of the total trade between Georgia and the UK has been uneven, with spikes of $f 217$ million in 2017 ( $25^{\text {th }}$ anniversary since the reestablishment of diplomatic relations) and declines up to $£ 100$ million in 2014 (Hubbard, 2021/a), a rather tumultuous year in terms of political events in the Black Sea region. In comparison with other countries in the region, UK's trade relations with Georgia are dominated by exports over import. For Georgia import from the UK in 2019 was $1.14 \%$ of the total value (Foreign and Commonwealth Office, 2019), and this value is lower than for the imports from Germany, Italy, France and Poland.

The agreement of 2019 duplicates many provisions of the EU-Georgia Association Agreement. The new Agreement with the UK covers all primary areas, such as political cooperation, conflict resolution, Euro-Atlantic integration of Georgia, defense and security, fight against crime and terrorism, free trade, economic cooperation and energy, tourism, environment, education, science, culture, etc. The Agreement highlights the progress made by Georgia towards its integration into the EU and NATO and restates the UK's support for Georgia's Euro-Atlantic aspirations (Foreign and Commonwealth Office, 2019). In political terms, the UK has justified its strong support for Georgia's sovereignty and territorial integrity.

The agreement establishes a free trade regime and provides the legal framework for the support and further deepening of the existing economic and business ties. For example, the effective since 2014 Wardrop Strategic Dialogue, bringing together key elements of UKGeorgia bilateral relations ranging from political matters to defense and security, including economic and trade ties, was envisaged to ensure the proper and smooth implementation of the Agreement.

\section{Ukraine}

Similarly, the Agreement replaced in the bilateral relations with the United Kingdom is the Association Agreement between Ukraine and the European Union. This agreement delivers the same level of liberalization in trade, services and public procurement that businesses currently enjoy under the existing EU-Ukraine Association Agreement. In 2020, the trade between the UK and Ukraine was worth $£ 1.3$ billion. Ukraine's exports to the UK accounted for $1.4 \%$ of total exports in 2020 (Foreign and Commonwealth Office, 2020/b).

For comparison, the bilateral trade between the two countries was also quite dynamic at the beginning of 2010s (for instance, the total trade value in 2011 was $f 1,354$ million), with a slight tumble in 2014-2015, and an increase of up to $£ 1,633$ million in 2019 (Hubbard, 2021/d). Back in 2010, the United Kingdom was the 6th largest investor in Ukraine's 
economy - in the first half of 2010, direct investment from the UK amounted to \$2228.1 million (accounting for 5th place among EU member states).

The EU's Common Agricultural Policy has burdened the UK, because the latter is primarily an importer not an exporter of food products. Hence the current Agreement with Ukraine will help Britain take care of its food security. Ukrainian food producers will benefit as well. Some experts argue that Ukraine was granted additional and better conditions for access to the EU and British markets than it used to have (Dordević, 2021). In addition, British producers will be able to sell more of their agricultural equipment to Ukrainian farmers, as the latter are quite dependent on it (Miroshnichenko, 2020). The introduction of tariff quotas means that certain goods will be supplied in certain volumes at a zero rate and imports of these goods in excess of a certain amount will be taxed under the same conditions that existed before the introduction of free trade with the UK. In turn, Ukraine has established tariff quotas for three types of goods, namely pork, poultry and sugar (Foreign and Commonwealth Office, 2020/b).

Just as in the case of Georgia, the Agreement underlines the UK's support for Ukraine's sovereignty and territorial integrity, as well as both countries' commitment to the strengthening of democracy and human rights and to the deepening of the security relationship. Ukraine and the United Kingdom agreed to coordinate sanctions policies and promote initiatives in international organizations.

\section{Turkey}

The UK and Turkey's trade relations are a totally different picture in comparison with Ukraine, Georgia and Moldova. Back in 2010, Turkey took the position of the United Kingdom's $19^{\text {th }}$ largest source of import and the $22^{\text {nd }}$ place as an export destination (House of Commons, 2012). At bilateral meetings at the beginning of 2010s, both sides declared their determination to double the UK-Turkey trade volume, just like it grew over the span of 2002-2012 by $180 \%$, from $f 1.71$ billion in 2002 to $f 4.79$ billion in 2012 (Buckle et al., 2015: 48).

In 2020, Turkey was the UK's 18th largest trading partner (which equals $1.3 \%$ of the United Kingdom's total trade), while the UK was the second-biggest export market for Turkey (after Germany). Over the last decade, the shipment between Turkey and the UK has surged by almost 70\% (Daily Sabah, 2021). In terms of political relations, the reciprocal visits paid by highest officials from both sides and the Turkish-British "Tathdel Forum" held regular annual meetings from 2011 until 2019. Turkey is identified as the British "strategic partner".

In 2020 the primary goods imported to the UK from Turkey were clothing ( $f 1.3$ billion or $16.0 \%$ of all goods imported from Turkey), electrical machinery $(11.0 \%)$, cars $(8.0 \%)$, road vehicles other than cars (7.3\%) and miscellaneous electrical goods (7.2\%) (Hubbard, 2021/c). Brexit and the transitioning period did have a significant impact on both sides: compared to 2019, the decrease of UK imports from Turkey by $9.4 \%$ ( $f 847$ million) exposed a mild disruption in regular trade patterns. Meanwhile, in contrast to 2019, UK imports 
of services from Turkey decreased by $64.3 \%$ ( $\mathrm{f1.7}$ billion) (Ibid.). Thus, both sides are interested in securing the previous level of trade and potentially further expanding trade flows in the future.

Also, Turkey is in a Customs Union with the EU, unlike the other countries discussed earlier. EU Customs Union and an FTA are two different concepts. Goods could profit from the free movement between member countries thanks to the Customs Union. However, under the Free Trade Agreement, products can only be traded tariff-free if they originate in one of the participating countries (Riddell and Bunch, 2021). In other words, tariff preferences will continue to favor the UK and Turkey only if products exchanged originate in either nation.

Currently, the UK-Turkey agreement's requirements pertaining to origin (the Rules of Origin Protocol) include a number of interim elements that will be modified in the near future to align with the UK-EU Trade Cooperation Agreement. What is interesting about the Turkish case is that the negotiations are still ongoing, and the agreement signed is seen only as a "first phase". Governments on both sides want to work towards a more comprehensive FTA. Nevertheless, exports from Turkey to the UK are already showing a positive dynamic and have increased by $36.6 \%$ in the first half of the year 2021 (Daily Sabah, 2021).

\section{Moldova}

The Strategic Partnership, Trade and Cooperation Agreement between the UK and Moldova replicates the effects of the existing EU-Moldova Association Agreement (signed in 2014) and Deep and Comprehensive Free Trade Agreement (DCFTA) provisions. As part of the Agreement, the UK recognizes and supports Moldova's commitment to an ambitious program of reforms and its political, economic and legal accomplishments (Foreign and Commonwealth Office, 2020/c). The agreement with the UK also establishes the creation of a high-level Political and Strategic Dialogue Platform, which will ensure the implementation of the Agreement. The first meeting of the Platform is scheduled for 2021.

The total trade in goods and services between the UK and Moldova was worth almost $\mathrm{f} 400$ million in 2019, which is quite low, bearing in mind the size of Moldova's economy (Ibid.), but still significantly bigger than the one with Georgia. It is worth noting that since 2011 the total trade has been steadily growing, from $£ 108$ million in 2011 to $£ 273$ million in 2018 (Hubbard, 2021/b). In 2020 the value of total trade spiked up to $\mathrm{f} 918$ million. Interestingly, the trade balance is dominated by exports from Moldova to the UK, including such goods as clothing, beverages, aircrafts and vegetables (Ibid.).

\section{Conclusion}

The results indicate that UK's trade with the countries in the Black Sea region (also quite affiliated with the EU) is likely to gain more importance in comparison with previous decades, which will broaden the opportunities for the UK to become more involved in the economy of the region and, potentially, build stronger and independent political ties 
with the examined countries. The analysis of the documents shows that the UK's strategy towards non-EU member states in this region is quite similar, with the exception of Turkey. It is too early to discuss the specific changes in trade relations, since such data are yet to gradually become available. However, the trade patterns in years 2020-2021 already illustrate certain positive changes in dynamics.

What is notable so far is that the relative ease with which the UK managed to secure agreements with both political and economic commitments to non-EU countries stands in contrast to the difficulty that Brussels experiences in the pursuit of a coordinated EU policy when it comes to European security matters and the relations with third countries. Further research could be conducted by comparing the dynamics in UK's trade relations in the Black Sea region with the signing of similar FTA's in the Mediterranean Sea region. In general, the study of the new framework of UK's trade relations with other countries opens up new prospects for a comparative research within regional studies.

\section{References}

Baier, S. L., and Bergstrand, J. H. (2007). "Do free trade agreements actually increase members' international trade?" In: Journal of International Economics, 71(1), pp. 72-95. https://doi.org/10.1016/j.jinteco.2006.02.005

Begović, S. (2011). "The Effect of Free Trade Agreements on Bilateral Trade Flows: The Case of Cefta". In: Zagreb International Review of Economics \& Business, 14(2), pp. 51-69.

Buckle, R., Hewish, T., Hulsman, J. C., Oulds, R., and Mansfield, I. G. (2015). Brexit: directions for Britain outside the EU. Institute of Economic Affairs.

Caporale, G. M., Rault, C., Sova, R., and Sova, A. (2009). "On the bilateral trade effects of free trade agreements between the EU-15 and the CEEC-4 countries". In: Review of World Economics, 145(2), pp. 189-206. https://doi.org/10.1007/s10290-0090011-8.

Daily Sabah. (2021, August 26). "Turkey, UK to start talks on more comprehensive free trade deal". In: Daily Sabah. Available at https://www.dailysabah.com/business/ turkey-uk-to-start-talks-on-more-comprehensive-free-trade-deal/news (last accessed 7 May, 2021).

Dordević, N. (2021). There's never been a better time for UK firms to explore Ukraine's potential - Emerging Europe. (online) Emerging Europe. Available at: https:// emerging-europe.com/news/theres-never-been-a-better-time-for-uk-firms-toexplore-ukraines-potential/ (last accessed 7 May, 2021).

Edgington, T. (2021). Brexit: What trade deals has the UK done so far? (online) BBC News. Available at: https://www.bbc.com/news/uk-47213842 (last accessed 28 Jun, 2021). Foreign and Commonwealth Office (2019). Strategic partnership agreement between the United Kingdom of Great Britain and Northern Ireland and Georgia (CS Georgia No.1/2019). London: Foreign and Commonwealth Affairs. Available at: https:// 
www.gov.uk/government/publications/ukgeorgia-strategic-partnership-andcooperation-agreement-cs-georgia-no12019 (last accessed 28 June, 2021).

Foreign and Commonwealth Office (2020/a). Free Trade Agreement between the United Kingdom of Great Britain and Northern Ireland and the Republic of Turkey (with Exchange of Letters). Ankara, 29 December 2020. Available at: https://www.gov.uk/ government/publications/ukturkey-free-trade-agreement-cs-turkey-no12021 (last accessed 25 June, 2021).

Foreign and Commonwealth Office (2020/b). Political, Free Trade and Strategic Partnership Agreement between the United Kingdom of Great Britain and Northern Ireland and Ukraine. London: Foreign and Commonwealth Affairs. Available at: https://www. gov.uk/government/publications/ukukraine-political-free-trade-and-strategicpartnership-agreement-cs-ukraine-no12020 (last accessed 23 June, 2021).

Foreign and Commonwealth Office (2020/c). Strategic Partnership, Trade and Cooperation Agreement between the United Kingdom of Great Britain and Northern Ireland and the Republic of Moldova. London: Foreign and Commonwealth Affairs. Available at: https://www.gov.uk/government/publications/ukmoldova-strategic-partnershiptrade-and-cooperation-agreement-cs-moldova-no12021 (last accessed 20 June, 2021).

Hubbard, B. (2021/a). Georgia: Trade \& Investment Factsheet. (online) www.gov.uk. Department of International Trade. Available at: https://assets.publishing.service. gov.uk/government/uploads/system/uploads/attachment_data/file/993622/ georgia-trade-and-investment-factsheet-2021-06-18.pdf (last accessed 28 June, 2021).

Hubbard, B. (2021/b). Moldova: Trade \& Investment Factsheet. (online) www.gov.uk. Department of International Trade. Available at: https://assets.publishing.service. gov.uk/government/uploads/system/uploads/attachment_data/file/993688/ moldova-trade-and-investment-factsheet-2021-06-18.pdf. (last accessed 20 June, 2021).

Hubbard, B. (2021/c). Turkey: Trade \& Investment Factsheet. (online) www.gov.uk. Department of International Trade. Available at: https://assets.publishing.service. gov.uk/government/uploads/system/uploads/attachment_data/file/993771/ turkey-trade-and-investment-factsheet-2021-06-18.pdf (last accessed 28 June, 2021).

Hubbard, B. (2021/d). Ukraine: Trade \& Investment Factsheet. (online) www.gov.uk. Department of International Trade. Available at: https://assets.publishing.service. gov.uk/government/uploads/system/uploads/attachment_data/file/993776/ ukraine-trade-and-investment-factsheet-2021-06-18.pdf (last accessed 18 June, 2021).

Hughes, L. (2021). "UK pins hope on joining US-Mexico-Canada trade pact". In: Financial Times. Available at: https://www.ft.com/content/b519921f-8d14-4948-9afaf2340b0d25d (last accessed 5 Sept., 2021) 
Kamath, R. (2021). Unlocking a new era: India-UK Early Harvest Trade Deal. Orfonline. org; Observational Research Foundation. Available at: https://www.orfonline. org/expert-speak/unlocking-a-new-era-india-uk-early-harvest-trade-deal/ (last accessed 5 Sept., 2021).

Miroshnichenko, V. (2020). "Brexit yak shans dlia eksportu: shcho dast Ukraini ZVT z Brytanieyu" (Brexit as a chance for export: What does Ukraine get from the Agreement with Britain). In: Yevropeiska Pravda. Available at: https://www.eurointegration. com.ua/experts/2020/10/8/7115143/ (last accessed 7 May, 2021).

Riddell, G. and Bunch, M. (2021). "What's the status of the UK's trade agreements with non-EU countries". (online) Ey.com. Available at: https://www.ey.com/en_uk/eybrexit/status-of-uk-trade-agreements-with-non-eu-countries (last accessed 7 May, 2021).

Saggi, K., and Yildiz, H. M. (2011). "Bilateral Trade Agreements and the Feasibility of Multilateral Free Trade". In: Review of International Economics, 19(2), 356-373. https://doi.org/10.1111/j.1467-9396.2011.00952.x

House of Commons. (2012). UK-Turkey relations and Turkey's regional role. Foreign Affairs Committee, UK. Available at: https://www.ab.gov.tr/files/ardb/evt/1_avrupa_ birligi/1_6_raporlar/1_3_diger/uk_tr_relations.pdf (last accessed 10 June, 2021).

Vicard, V. (2011). "Determinants of successful regional trade agreements". In: Economics Letters, 111(3), 188-190. https://doi.org/10.1016/j.econlet.2011.02.010

Yamarik, S., and Ghosh, S. (2005). "A Sensitivity Analysis of the Gravity Model". In: The International Trade Journal, 19(1), pp. 83-126. https://doi. org/10.1080/08853900590905784 